\title{
Survival of Didymella bryoniae Incitant of Ridge Gourd Blight Under Temperate Conditions
}

\author{
Z.A. Bhat*, M.A. Bhat, M.A. Ahanger, Z.A. Badri, G.H. Mir and F.A. Mohi-u-Din \\ Division of Plant Pathology, Sher-e-Kashmir University of Agricultural Sciences and \\ Technology of Kashmir Shalimar Campus-190025, India \\ *Corresponding author
}

\section{A B S T R A C T}

\begin{tabular}{|l|}
\hline Ke y w or d s \\
$\begin{array}{l}\text { Didymella } \\
\text { bryoniae, } \\
\text { Perpetuation, Plant } \\
\text { debris, Ridge gourd }\end{array}$ \\
\hline Article Info \\
\hline $\begin{array}{l}\text { Accepted: } \\
\text { 20 April } 2018 \\
\text { Available Online: } \\
\text { 10 May } 2018\end{array}$ \\
\hline
\end{tabular}

\section{Introduction}

Didymella bight caused by Didymella bryoniae (Aures.) Rehm. (anamorph: Phoma cucurbitacearum (Foutry) Sacardo) is an important disease of all the cucurbitaceous crops and reduces their yield as a result of defoliation, fruit infection and subsequent decay (Schenck, 1968). The disease is widely distributed in tropical countries and also reported frequently in areas having temperate climate (Sitterly, 1969). The disease was first reported from France in 1891 on cucumber (Roumeguere, 1891) and since then it has been reported from many countries namely, USA, Britain, Germany, Japan, New Zealand,
Brunei, Mexico, Netherlands, Republic of Ireland, Salvadar (Puninthalingam and Holliday, 1972). In India, the disease was first reported from Mysore on leaves of Scheum edule (Sohi and Prakash, 1972) and then subsequently on Cucumis sativus (Kumar and khan, 1984), Mamordicha charanta (Kulwant and Shetty, 1996), Benincasa hispida (Pandey and Pandey, 2003) and Cucumis melo (Sudisha et al., 2004). Yield losses due to this disease on watermelon have been estimated up 100 per cent in Trindad (Bala and Hosein, 1986), 43 per cent in USA (Kienath and Duthie, 1998), 30 per cent on muskmelon in Australia (Mc Grath et al., 1993) and 35 per cent on cucumber in Polland (Leski, 1984). 
The disease has emerged in the recent past as one of the major constraints in the successful cultivation of the crop in Kashmir valley and has been responsible for causing a marked reduction in both quality and quantity of the fruit yield. For an effective management of the disease mode of perpetuation of the pathogen during the crop-less off-season is imperative.

The present study was therefore, conducted under temperate conditions of Kashmir valley to find out the role of infected crop debris and seeds in perpetuation of the pathogen.

\section{Materials and Methods}

\section{Perpetuation in/on seed}

The seeds collected at harvest from severely infected ridge gourd plants were stored in cotton cloth bags in laboratory and assessed for presence of the pathogen through blotter and agar plate methods at monthly intervals.

\section{Blotter method}

Random sample of sixty seeds were taken at monthly intervals from harvest and surface sterilized by immersing in $0.1 \%$ mercuric chloride for one minute followed by three subsequent rinses with sterilized distilled water. The seeds were placed in sterilized Petri dishes on three folds of sterilized blotter papers moistened with sterilized distilled water. Twenty seeds were placed aseptically in each Petri dish maintaining three replications for each plate. The plates were incubated at $24 \pm 1^{\circ} \mathrm{C}$.

The blotter paper in Petri dishes was kept moist by carefully pouring a few drops of sterilized distilled water in the plates as and when required. The plates were examined from $4^{\text {th }}$ up to $15^{\text {th }}$ day after incubation for the appearance of fungal colonies.

\section{Agar plate method}

Sixty seeds were taken from the seed lot and surface sterilized. Twenty surface sterilized seeds were aseptically placed on 2 per cent water agar in Petri dishes and incubated at $24 \pm 1^{\circ} \mathrm{C}$. The plates were examined from $4^{\text {th }}$ to $10^{\text {th }}$ day after incubation for recording the percentage of seeds showing D. bryoniae growth.

The number of seeds showing $D$. bryoniae growth in blotter and agar plate method were recorded and per cent infected seeds estimated by using the formula:

\begin{tabular}{ll} 
Per cent infected & $\begin{array}{c}\text { Number of seed } \\
\text { infected }\end{array}$ \\
\cline { 2 - 2 } seeds $=$ & $\begin{array}{c}\text { Total number of } \\
\text { seeds examined }\end{array}$
\end{tabular}

\section{Spore viability}

Twenty ridge gourd seeds were taken randomly at monthly intervals from harvest and $1 \mathrm{~cm}^{2}$ hilum portion from each seed carved out and crushed in a pestle and mortar in $40 \mathrm{ml}$ of distilled water. The crushed material was strained through a double layer of cheese cloth. Twenty milliliter of the filtrate was centrifuged at $6000 \mathrm{rpm}$ for 15 minutes. After centrifugation, supernatant was discarded and pellet was made 5 milliliter by adding sterilized water (Filajdic and Sutton, 1995). Number of pycnidiospores/ ascospores was counted with the help of haemocytometer and the average spore load of three replications was estimated. To estimate the pycnidiospore/ ascospore germination one drop of $50 \mu \mathrm{l}$ from processed sample was placed on a glass slide and incubated in a moist chamber at $24 \pm 1^{\circ} \mathrm{C}$. After 24 hour incubation, the slide was viewed under binocular microscope to record spore germination index of spore viability. The spore viability was recorded using the formula: 


\begin{tabular}{|c|c|}
\hline Spore & $\begin{array}{c}\text { Number of spores } \\
\text { germinated }\end{array}$ \\
\hline viabili & $\begin{array}{l}\text { Total number of } \\
\text { spores viewed }\end{array}$ \\
\hline
\end{tabular}

\section{Perpetuation through plant debris}

The infected plant debris including fruit husk and leaves were collected at harvest from the diseased crop and kept separately in nylon mesh bags. The bags were divided into three sets of 12 bags each. One set, each of leaves and fruit husk, was placed on the soil surface in vacated ridge gourd fields. The other set was buried $7.5 \mathrm{~cm}$ deep in such soil and third set was stored under ambient laboratory conditions. Each set was replicated three times. One month after placement of the bags at appropriate positions, twenty bits of $1 \mathrm{~cm}^{2}$ area were randomly taken from one randomly selected bag of each leaf and fruit husk and examined for the presence of pycnidia/pseudothecia. These leaf and fruit discs were then crushed separately in $40 \mathrm{ml}$ of sterilized distilled water and for spore suspension preparation and estimation of per cent viability of pycnidiospores/ascospores the method as described above for spore viability test of infected seeds was adopted.

\section{Results and Discussion}

\section{Survival on seed}

The seeds were found infected with $D$. bryoniae and the infection was found to persist from harvest up to 12 months of storage under ambient room conditions by using blotter and agar plate methods (Table 1). Similarly, the seeds were found to harbour viable spores of $D$. bryoniae throughout the observation period of twelve months starting from one month after harvest (in November during both the crop seasons of 2004 and 2005). The extent of viability constantly decreased with the advancement of storage period such that after 12 months of storage seeds harboured 18.6 and 20.3 per cent viable conidia in 2004 and 2005, respectively (Table $1)$.

Table.1 Survival of Didymella bryoniae in/on ridge gourd seeds observed at monthly intervals after harvest in 2004 and 2005

\begin{tabular}{|l|l|l|l|l|l|l|}
\hline & \multicolumn{3}{l}{ Month } & & \multicolumn{3}{l}{ Seeds showing D. bryoniae growth (\%) } \\
\cline { 2 - 6 } & $\mathbf{2 0 0 4}$ & $\mathbf{2 0 0 5}$ & $\mathbf{2 0 0 4}$ & $\mathbf{2 0 0 5}$ & $\mathbf{2 0 0 4}$ & $\mathbf{2 0 0 5}$ \\
\hline November 2004 & $93.9(76.0)$ & $93.7(75.9)$ & $45.0(42.1)$ & $48.3(44.0)$ & $41.6(40.1)$ & $45.0(42.1)$ \\
\hline December & $95.4(77.8)$ & $92.9(74.7)$ & $41.6(40.1)$ & $45.0(42.1)$ & $38.3(38.2)$ & $43.3(41.1)$ \\
\hline January 2005 & $81.2(64.3)$ & $86.9(68.9)$ & $38.3(38.2)$ & $41.6(40.1)$ & $36.6(37.2)$ & $38.3(38.2)$ \\
\hline February & $72.0(58.0)$ & $80.8(64.0)$ & $33.3(35.2)$ & $38.3(38.2)$ & $33.3(35.1)$ & $35.0(36.2)$ \\
\hline March & $61.3(51.5)$ & $78.0(62.0)$ & $31.6(34.2)$ & $35.0(36.2)$ & $31.6(34.2)$ & $28.3(32.1)$ \\
\hline April & $55.9(48.4)$ & $73.2(58.8)$ & $30.0(33.1)$ & $31.6(34.2)$ & $28.3(32.0)$ & $25.0(29.9)$ \\
\hline May & $32.5(34.7)$ & $60.8(51.2)$ & $28.3(32.1)$ & $30.0(33.1)$ & $25.0(29.9)$ & $23.3(28.8)$ \\
\hline June & $29.8(33.0)$ & $46.6(43.0)$ & $26.6(30.9)$ & $26.6(30.9)$ & $21.6(27.6)$ & $21.6(27.5)$ \\
\hline July & $28.0(31.9)$ & $45.9(42.6)$ & $23.3(28.8)$ & $25.0(29.9)$ & $20.0(26.4)$ & $21.6(27.5)$ \\
\hline August & $28.35(32.0)$ & $32.6(34.8)$ & $20.0(26.4)$ & $21.6(27.5)$ & $16.6(24.0)$ & $20.0(26.5)$ \\
\hline September & $23.3(28.8)$ & $24.1(29.4)$ & $20.0(26.5)$ & $20.0(26.4)$ & $11.6(19.8)$ & $15.0(22.5)$ \\
\hline October & $18.6(25.5)$ & $20.3(26.7)$ & $16.6(24.0)$ & $18.3(25.2)$ & $8.3(16.5)$ & $11.6(19.8)$ \\
\hline CD (P=0.05) & 4.69 & 3.88 & 4.32 & 4.43 & 4.92 & 4.58 \\
\hline
\end{tabular}

Figures in parentheses are arc sine transformed values 
Table.2 Fructification and pycnidiospore/ ascospore production and viability on infected ridge gourd leaves kept under different conditions after harvest in 2004 and 2005

\begin{tabular}{|c|c|c|c|c|c|c|c|c|c|c|c|c|c|c|c|c|c|}
\hline \multirow[t]{4}{*}{ Month } & \multicolumn{6}{|c|}{$\begin{array}{c}* \text { No. of pycnidia/ pseudothecia } \mathrm{cm}^{-2} \text { fruit husk } \\
\text { area }\end{array}$} & \multicolumn{6}{|c|}{$\begin{array}{c}\text { *No. of pycnidiospores/ ascospores } \mathrm{cm}^{-2} \text { fruit } \\
\text { husk area }\end{array}$} & \multicolumn{5}{|c|}{ *Pycnidiospore/ ascospore viability (\%) } \\
\hline & \multirow{2}{*}{\multicolumn{2}{|c|}{$\begin{array}{l}\text { Ambient } \\
\text { conditions }\end{array}$}} & \multicolumn{4}{|c|}{ Leaf burial at soil depth $(\mathrm{cm})$} & \multirow{2}{*}{\multicolumn{2}{|c|}{$\begin{array}{l}\text { Ambient } \\
\text { conditions }\end{array}$}} & \multicolumn{4}{|c|}{ Leaf burial at soil depth $(\mathrm{cm})$} & \multirow{2}{*}{\multicolumn{2}{|c|}{ Ambient conditions }} & \multicolumn{3}{|c|}{ Leaf burial at soil deptl } \\
\hline & & & & & & & & & & & & & & & $\mathbf{0}$ & & 7.5 \\
\hline & 2004 & 2005 & 2004 & 2005 & 2004 & 2005 & 2004 & 2005 & 2004 & 2005 & 2004 & 2005 & 2004 & 2005 & 2004 & 2005 & 2004 \\
\hline November 2004 & 47.6 & 49.8 & 45.6 & 49.8 & 17.2 & 23.6 & 5166 & 4643 & 4100 & 3956 & 0.0 & 0.0 & $90.4(72.1)$ & $87.6(69.3)$ & 92.2 & 90.1 & NA \\
\hline December & 40.1 & 46.9 & 34.2 & 39.5 & 0.0 & 0.0 & 3646 & 3916 & 3453 & 3126 & 0.0 & 0.0 & $76.5(61.0)$ & $73.2(58.8)$ & 81.2 & 86.9 & NA \\
\hline January 2005 & 38.0 & 44.9 & 21.2 & 18.0 & 0.0 & 0.0 & 3166 & 2926 & 0 & 0 & 0.0 & 0.0 & $64.0(53.1)$ & $58.6(49.9)$ & NA & NA & NA \\
\hline February & 31.2 & 39.9 & 13.2 & 10.2 & 0.0 & 0.0 & 2643 & 2336 & 0 & 0 & 0.0 & 0.0 & $48.4(44.1)$ & $49.0(44.4)$ & NA & NA & NA \\
\hline March & 23.5 & 33.0 & 19.4 & 20.7 & - & - & 1833 & 2173 & 1846 & 2100 & - & - & $30.3(33.5)$ & $38.4(38.3)$ & 85.2 & 82.6 & NA \\
\hline April & 20.6 & 29.0 & 29.6 & 20.0 & - & - & 1413 & 1856 & 2533 & 2836 & - & - & $23.3(28.8)$ & $35.0(36.2)$ & 94.4 & 80.2 & - \\
\hline May & 18.5 & 21.3 & 24.5 & 17.4 & - & - & 1046 & 1643 & 2013 & 2126 & - & - & $20.3(26.7)$ & $32.7(34.9)$ & 84.8 & 80.0 & - \\
\hline June & 12.1 & 16.4 & 19.5 & 11.6 & - & - & 1026 & 1393 & 1226 & 1640 & - & - & $20.0(26.5)$ & $28.9(32.5)$ & 78.6 & 73.4 & - \\
\hline July & 10.9 & 15.1 & - & - & - & - & 956 & 876 & - & - & - & - & $16.4(23.9)$ & $24.2(29.4)$ & - & - & - \\
\hline August & 12.5 & 12.6 & - & - & - & - & 646 & 630 & - & - & - & - & $10.4(18.8)$ & $19.0(25.9)$ & - & - & - \\
\hline September & 8.5 & 9.5 & - & - & - & - & 576 & 646 & - & - & - & - & $9.6(18.0)$ & $13.7(21.7)$ & - & - & - \\
\hline October & 6.5 & 8.3 & - & - & - & - & 416 & 343 & - & - & - & - & $8.8(17.2)$ & $7.2(15.6)$ & - & - & - \\
\hline $\mathrm{CD}(\mathrm{P}=0.05)$ & 2.90 & 3.07 & 3.28 & 2.54 & & & 2.95 & 3.23 & 2.59 & 3.18 & & & 2.60 & 3.29 & & & \\
\hline
\end{tabular}

Figures in parentheses are arc sine transformed values

- Material perished; NA Spores not available 
Table.3 Fructification and pycnidiospore/ ascospore production and viability on infected ridge gourd fruit husk kept under different conditions after harvest in 2004 and 2005

\begin{tabular}{|c|c|c|c|c|c|c|c|c|c|c|c|c|c|c|c|c|c|c|}
\hline \multirow[t]{4}{*}{ Month } & \multicolumn{6}{|c|}{$\begin{array}{c}\text { *No. of pycnidia/ pseudothecia } \mathrm{cm}^{-2} \text { fruit husk } \\
\text { area }\end{array}$} & \multicolumn{6}{|c|}{$\begin{array}{l}\text { *No. of pycnidiospores/ ascospores } \mathrm{cm}^{-2} \text { fruit } \\
\text { husk area }\end{array}$} & \multicolumn{6}{|c|}{ *Pycnidiospore/ ascospore viability (\%) } \\
\hline & \multirow{2}{*}{\multicolumn{2}{|c|}{$\begin{array}{l}\text { Ambient } \\
\text { conditions }\end{array}$}} & \multicolumn{4}{|c|}{ Leaf burial at soil depth $(\mathrm{cm})$} & \multirow{2}{*}{\multicolumn{2}{|c|}{$\begin{array}{l}\text { Ambient } \\
\text { conditions }\end{array}$}} & \multicolumn{4}{|c|}{ Leaf burial at soil depth $(\mathrm{cm})$} & \multicolumn{2}{|c|}{ Ambient conditions } & \multicolumn{4}{|c|}{ Leaf burial at soil depth $(\mathrm{cm})$} \\
\hline & & & & & & & & & & & & & & & $\mathbf{0}$ & & 7.5 & \\
\hline & 2004 & 2005 & 2004 & 2005 & 2004 & 2005 & 2004 & 2005 & 2004 & 2005 & 2004 & 2005 & 2004 & 2005 & 2004 & 2005 & 2004 & 2005 \\
\hline November 2004 & 78.1 & 71.8 & 76.6 & 71.8 & 13.4 & 24.6 & 6926 & 6576 & 6126 & 4936 & 0.0 & 0.0 & $94.2(66.5)$ & $93.2(74.9)$ & 92.05 & 91.1 & NA & NA \\
\hline December & 70.8 & 69.2 & 63.2 & 53.6 & 0.00 & 0.0 & 6200 & 5963 & 4533 & 3863 & 0.0 & 0.0 & $84.6(59.7)$ & $89.4(71.0)$ & 87.33 & 88.7 & NA & NA \\
\hline January 2005 & 62.4 & 65.7 & 36.7 & 30.6 & 0.00 & 0.0 & 5036 & 5376 & 0 & 0 & 0.0 & 0.0 & $72.5(52.2)$ & $77.1(61.4)$ & NA & NA & NA & NA \\
\hline February & 54.4 & 57.8 & 22.2 & 10.5 & 0.00 & 0.0 & 4520 & 4656 & 0 & 0 & 0.0 & 0.0 & $51.2(45.7)$ & $53.2(46.8)$ & NA & NA & NA & NA \\
\hline March & 43.2 & 52.1 & 24.2 & 19.4 & 0.00 & - & 3865 & 4226 & 2946 & 1453 & - & - & $43.2(41.1)$ & $45.2(42.2$ & 89.55 & 90.6 & - & - \\
\hline April & 37.1 & 47.1 & 41.0 & 37.2 & - & - & 3353 & 3623 & 3756 & 2100 & - & - & $41.5(40.1)$ & $33.2(35.2)$ & 88.05 & 82.4 & & - \\
\hline May & 30.2 & 37.2 & 25.1 & 18.2 & - & - & 2850 & 3150 & 2253 & 1353 & - & - & $38.4(38.2)$ & $29.8(33.0)$ & 85.16 & 80.2 & - & - \\
\hline June & 24.1 & 31.4 & 18.4 & 12.5 & - & - & 2630 & 2413 & 1676 & 1000 & - & - & $32.0(34.4)$ & 23.4 & 80.38 & 75.1 & - & - \\
\hline July & 20.2 & 21.5 & 13.2 & 9.2 & - & - & 1746 & 1853 & 1240 & 813 & - & - & $28.4(32.2)$ & $24.2(29.4)$ & 78.25 & - & - & - \\
\hline August & 14.1 & 19.6 & - & - & - & - & 1573 & 1356 & - & - & - & - & $22.5(28.3)$ & $21.0(27.3)$ & - & - & - & - \\
\hline September & 10.1 & 13.5 & - & - & - & - & 1256 & 923 & - & - & - & - & $18.5(25.5)$ & $16.2(23.7)$ & - & - & - & - \\
\hline October & 8.2 & 10.5 & - & & - & - & 983 & 780 & - & & - & - & $13.2(21.3)$ & $11.8(20.1)$ & - & - & - & - \\
\hline $\mathrm{CD}(\mathrm{P}=\mathbf{0 . 0 5})$ & 2.27 & 2.83 & 3.25 & 3.10 & & & 3.20 & 3.29 & 3.64 & 2.41 & & & 0.91 & 1.57 & & & & \\
\hline
\end{tabular}

Figures in parentheses are arc sine transformed values - Material perished; NA Spores not available 
These findings provide sufficient grounds to infer that the pathogen $D$. bryoniae perpetuates in/on the seeds as spores and the pathogen inoculum reaches the cropping fields along with seeds. Similar observations have also been made by several workers. Rankin (1954) found the invasion of $D$. bryoniae in the epidermis and sclerenchyma layers and isolated the fungus from cotyledons and embryo. Chen and Bao (1990) noted the survival of the fungus both in and on the seeds of infected fruits up to 21 months of storage at room temperature. Sudisha et al., (2006) also reported the seed borne nature of D. bryoniae and noted mean incidence of 31 per cent in seed coat, 11 per cent in cotyledons and 4 per cent in embryo while evaluating the different components of infected seeds.

\section{Survival on plant debris}

The periodic examination of the infected debris placed indoors, on soil surface and buried under soil indicated the presence of fruiting bodies as well as viable spores throughout the observation period of twelve months when placed indoors under roof protection and only up to four to five months when left on soil surface as debris perished beyond this period (Table 2 and 3). However, only empty fruiting bodies were noticed during January and February when left on the ground surface, suggesting the survival of $D$. bryoniae as dormant mycelium. The survival of the pathogen lasted for only four to five months when buried in soil, beyond this period debris was decomposed. The lower recovery rate of $D$. bryoniae from the infected plant debris buried in soil or placed on soil surface could be because of the fact that the hibernating pathogen was exposed to chilly winters, and had to compete with other soil inhabiting microorganisms for food and niche, a situation quite different than the one when the trash is stored under roof protection.
Kienath (2002) could not recover D. bryoniae beyond 6 to 7 months of storage in buried infected watermelon debris which he attributed to the antagonistic activities of saprophytic soil microorganisms that seemed to have eliminated the pathogen resident in the watermelon debris. Van Steekelenburg (1983) observed old pseudothecia with ascospores and pycnidia with some pycnidiospores, even after storage of diseased plant debris for 18 months, whereas on debris kept on soil surface in open only empty fruiting bodies were observed during winter months when average monthly temperature was below $5^{\circ} \mathrm{C}$. Similarly, Chiu and Walker (1949) found empty pycnidia and pseudothecia in the overwintered crop debris but could isolate the fungus readily and suggested the overwintering of fungus in winter as dormant mycelium.

\section{References}

Bala, G. and Hosein, F. 1986. Studies on gummy stem blight disease of cucurbits in Trinidad. Tropical Agriculture 63: 195-197.

Chen, X. and Bao, J.R. 1990. Studies on gummy stem blight of watermelon, seed borne athogen and its infectivity. Acta Agriculture Universitatis Zhejiangensis 16: 258262.

Chiu, W.F. and Walker, J.C. 1949. Morphology and variability of the cucurbit black rot fungus. Journal of Agricultural Research 78: 81-102.

Filajdic, N. and Sutton, T.B. 1995. Overwintering of Alternaria mali, the casual agent of Alternaria blotch of apple. Plant Disease 79: 695-698.

Keinath, A.P. 2002. Survival of Didymella bryoniae in buried watermelon vines in South Carolina. Plant Disease 86: 32-38. 
Keinath, A.P. and Duthie, J.A. 1998. Yield and quality reductions in watermelon due to anthracnose, gummy stem blight and black rot. Recent Research Developments in Plant Pathology 2: 77-90.

Kulwant, S. and Shetty, K.P.V. 1996. Didymella black fruit rot of bittergourd. Indian Phytopathology 49: 294-296.

Kumar, R. and Khan, M.T. 1984. Leaf spot disease of Cucumis sativus. Indian Phytopathology 37: 374.

Leski, B. 1984. Black fruit and stem rot caused by Didymella bryoniae an important disease of glasshouse cucumber, new to Poland. Acta Horticulturae 156: 245-251.

Mc Grath, D.J., Vawdrey, L. and Walker, I.O. 1993. Resistance to gummy stem blight in muskmelon. HortScience. 28:930-931.

Pandey, K.K. and Pandey, P.K. 2003. First report of some new fungal diseases on wax gourd (Benincasa hispida) in the world from India. Journal of Mycology and Plant Pathology 33: 439-441.

Puninthalingam, E. and Holliday, E. 1972. Didymella bryoniae. CMI Descriptions of Pathogenic Fungi and Bacteria. No. 332. Common Wealth Mycological Institute, Ferry Lane, Kew, U.K.

Rankin, H.W. 1954. Effectiveness of seed treatments for controlling anthracnose and gummy stem blight of watermelon. Phytopathology 44: 675680.

Roumeguere, C. 1891. Fungi exsiccate precipue gallici. Revue Mycologia 13: 73-78.

Schenck, N.C. 1968. Epidemiology of gummy stem blight (Mycosphaerella citrullina) on watermelon: Ascospore incidence and disease development. Phytopathology 58: 1420-1422.

Sitterly, W. R. 1969. Effect of crop rotation on cucumber gummy stem blight. Plant Disease Reporter 53: 417-419.

Sohi, H.S. and Prakash, O. 1972. New records of fungal diseases from India. Indian Journal of Mycology and Plant Pathology 2: 139-142.

Sudisha, J., Kumar, T. V., Niranjana, S.R. and Shetty, H.S. 2004. First report of gummy stem blight caused by Didymella bryoniae on muskmelon (Cucumis melo) in India. Plant Pathology 53: 533.

Sudisha, J., Niranjana, S.R., Umesha, S., Prakash, H.S. and Shetty, H.S. 2006. Transmission of seed borne infection of muskmelon by Didymella bryoniae and effect of seed treatments on disease incidence and fruit yield. Biological Control 37: 196-205.

Van Steekelenburg, N.A.M. 1983. Epidemiological aspects of Didymella bryoniae, the cause of stem and blight rot of cucumber. Netherland Journal of Plant Pathology 89: 75-86.

\section{How to cite this article:}

Bhat, Z.A., M.A. Bhat, M.A. Ahanger, Z.A. Badri, G.H. Mir and F.A. Mohi-u-Din. 2018. Survival of Didymella bryoniae Incitant of Ridge Gourd Blight Under Temperate Conditions. Int.J.Curr.Microbiol.App.Sci. 7(05): 2632-2638. doi: https://doi.org/10.20546/ijcmas.2018.705.305 